\title{
Pioneering meiotic recombination
}

\author{
Kris G. Alavattam, ${ }^{1,2,3}$ Hironori Abe, ${ }^{1,2,3}$ and Satoshi H. Namekawa ${ }^{1,2,3}$ \\ ${ }^{1}$ Division of Reproductive Sciences, ${ }^{2}$ Division of Developmental Biology, ${ }^{3}$ Department of Pediatrics, University of Cincinnati \\ College of Medicine, Cincinnati, Ohio, 45229, USA
}

To induce cell type-specific forms of gene regulation, pioneer factors open tightly packed, inaccessible chromatin sites, enabling the molecular machinery to act on functionally significant information encoded in DNA. While previous studies of pioneer factors have revealed their functions in transcriptional regulation, pioneer factors that open chromatin for other physiological events remain undetermined. In this issue of Genes \& Development, Spruce and colleagues (pp. 398-412) report the functional significance of a "pioneer complex" in mouse meiotic recombination. This complex, comprised of the zinc finger DNA-binding protein PRDM9 and the SNF2 family chromatin remodeler HELLS, exposes nucleosomal DNA to designate the sites of DNA double-strand breaks that initiate meiotic recombination. Both HELLS and PRDM9 are required for the determination of these recombination hot spots. Through the identification of a pioneer complex for meiotic recombination, this study broadens the conceptual scope of pioneer factors, indicating their functional significance in biological processes beyond transcriptional regulation.

In order for cells to obtain cell type-specific functions, certain information-bearing sequences of DNA, termed regulatory elements, must be accessible to the molecular machinery. Barriers to regulatory elements must be removed, an aspect of developmental regulation that emerged in the context of transcription. One class of transcription factors, "pioneer factors," opens otherwise inaccessible chromatin to expose the cell type-specific regulatory elements that define transcription programs, thereby enabling cell fate decisions (Iwafuchi-Doi and Zaret 2014). Pioneer transcription factors bind DNA in a "closed" chromatin state-i.e., surrounded by arrays of nucleosomes-to increase the accessibility of target sites. Then, other proteins, including nonpioneer transcription factors and chromatin remodelers, are recruited to and/ or function at the newly opened sites. Although the regulation of chromatin accessibility is essential for various physiological processes, the pioneer mechanisms by

[Keywords: H3K4me3; chromatin remodeling; germ cells; histone modification; meiosis; nucleosome-depleted region; pioneer factor] Corresponding author: satoshi.namekawa@cchmc.org

Article is online at http://www.genesdev.org/cgi/doi/10.1101/gad.336438. 120. which nucleosomal DNA becomes accessible have remained for the large part unknown, and how they function outside the context of transcriptional regulation is mostly a mystery.

In this issue of Genes \& Development, Spruce et al. (2020) report a novel pioneer mechanism distinct from the established functions of pioneer factors in transcriptional regulation: the regulation of meiotic recombination. An essential hallmark of sexual reproduction, meiotic recombination promotes the shuffling of genetic material between maternal and paternal alleles, which fosters genetic diversity in offspring (Hunter 2015). In various species of mammals, chromatin state-in particular, chromatin bearing the histone modification H3K4me3directs the catalysis of programmed DNA double-strand breaks (DSBs) at specific regions of DNA. The formation of DSBs at these regions, which are frequent in the meiotic cell population and are termed "hot spots," are mediated by the enzyme SPO11 and comprise the initial step of meiotic recombination. This mechanism is in contrast to the recombination that takes place in somatic cells, where chromatin is remodeled not before but after the formation of nonprogrammed DSBs. Thus, there exists an exclusive and intricate mechanism for the determination of meiotic recombination hot spots in germ cells. Spruce et al. (2020) have systematically analyzed the epigenomic features of recombination hot spots in mouse spermatogenesis, reporting that hot spots bear a chromatin state distinct from other regulatory elements (Spruce et al. 2020).

In the initial step of meiotic recombination, the zinc finger DNA-binding protein PRDM9 (also known as Meisets) determines the locations of DSB hot spots (Grey et al. 2018; Paigen and Petkov 2018). A member of the PRDM family of transcription factors, PRDM9 is a rapidly evolved protein with a sequence-specific DNA-binding domain that is diverged among species and, remarkably, even among strains of the same species. PRDM9 recognizes and defines specific hot spots, mediating the deposition of histone modifications such as $\mathrm{H} 3 \mathrm{~K} 4 \mathrm{me} 3$ and H3K36me3. PRDM9 also binds the centers of

(C) 2020 Alavattam et al. This article is distributed exclusively by Cold Spring Harbor Laboratory Press for the first six months after the full-issue publication date (see http://genesdev.cshlp.org/site/misc/terms.xhtml). After six months, it is available under a Creative Commons License (Attribution-NonCommercial 4.0 International), as described at http://creativecommons.org/licenses/by-nc/4.0/. 
recombination hot spots, which are depleted of nucleosomes (Baker et al. 2014; Lange et al. 2016). The work by Spruce et al. (2020) advances our understanding of PRDM9's functions. Through the analyses of ATAC-seq lassay for transposase-accessible chromatin using sequencing) data, the team detected open chromatin at nucleosome-depleted regions in mouse spermatocytes. Then, using various genetic strategies, the team detected strain-specific PRDM9-binding sites and demonstrated that PRDM9 is required for the formation of open chromatin at hot spots-evidence of a pioneer function.

Next, Spruce et al. (2020) sought to understand the nature of PRDM9's pioneer activity. Drawing on previous work in which spermatocytes deficient for the gene Hells exhibited severe meiotic defects (Zeng et al. 2011), Spruce et al. (2020) hypothesized that HELLS, a SNF2 family chromatin remodeler, is involved in the PRDM9-dependent opening of chromatin at recombination hot spots. Their data indicate that HELLS and PRDM9 function as a "pioneer complex" for recombination hot spots, a conclusion supported by several independent, complementary results. Of note, in Hells mutant spermatocytes, meiotic DSBs occur not at PRDM9-dependent recombination hot spots but instead within gene promoters, a phenotype consistent with that of Prdm9 mutant spermatocytes (Brick et al. 2012). Thus, on a genetic level, both PRDM9 and HELLS are required for the determination of hot spots. Through mouse experiments and experiments that recapitulate hot spot determination in cultured human cells, the team found that (1) PRDM9 is required for the recruitment of HELLS to hot spots, (2) HELLS is required for robust PRDM9-binding at hot spots, and (3) HELLS and PRDM9 interact independent of DNA binding. Taken together, PRDM9 and HELLS form a pioneer complex that is required for the formation of open chromatin at and determination of hot spots (Fig. 1A).

Intriguingly, only when HELLS and PRDM9 are together do they fulfill pioneer functions-and only at recombination hot spots. In wild-type spermatocytes, HELLS is found at both hot spots and gene promoters; however, pioneer activity appears to be specific to hot spots. In mouse spermatogenesis, the chromatin at recombination hot spots is not open before or after the time of recombination, although the chromatin at promoters remains open throughout spermatogenesis (Maezawa et al. 2018). Through the identification of a functionally critical HELLS-PRDM9 pioneer complex, Spruce et al. (2020) have exposed several directions for future research. For example, given the various interaction partners reported for PRDM9 (Grey et al. 2018; Paigen and Petkov 2018), it is important to determine how interactions between PRDM9 and HELLS regulate chromatin environments versus interactions between PRDM9 and other factors. Moreover, since HELLS was reported to be required for female meiotic prophase (De La Fuente et al. 2006), it is important to investigate the functions of the HELLSPRDM9 complex in female meiosis. Given the strainand species-specific functions of PRDM9, understanding the evolution of the HELLS-PRDM9 complex makes for another intriguing scientific goal.

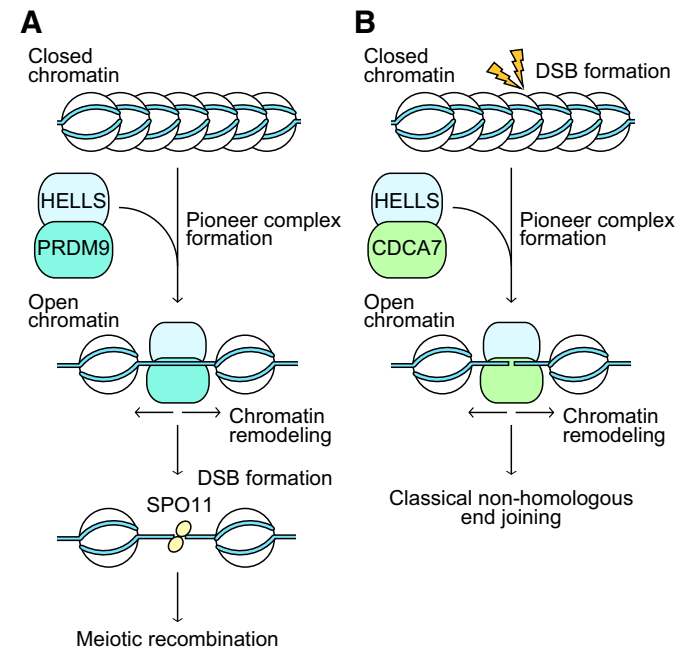

Figure 1. Models for pioneer complexes in meiotic recombination and classical nonhomologous end joining. (A) A HELLSPRDM9 protein complex is necessary for the formation of open chromatin at and the determination of meiotic recombination hot spots. (B) A HELLS-CDCA7 protein complex pioneers a chromatin state amenable to classical nonhomologous end joining.

Before now, studies of pioneer factors have focused on transcription factors with the ability to open inaccessible chromatin themselves (Iwafuchi-Doi and Zaret 2014). The work of Spruce et al. (2020) presents the new concept of a "pioneer complex" comprised of a DNA-binding protein and a chromatin remodeler. Consistent with this, HELLS forms a bipartite complex with the CXXC-type zinc finger protein CDCA7, which functions in classical nonhomologous end joining (cNHEJ) (Jenness et al. 2018; Unoki et al. 2019). Given that mutations in CDCA7 and HELLS cause immunodeficiency, centromeric instability, and facial anomalies (Jenness et al. 2018; Unoki et al. 2019), it is interesting to speculate that a HELLSCDCA7 complex pioneers, in part or whole, a chromatin state amenable to cNHEJ (Fig. 1B). In cNHEJ, DSB formation is not programmed and precedes chromatin events, a reversal of events in meiotic recombination. That said, perhaps cNHEJ and meiotic recombination share something in common: the preparation of a "pioneered chromatin state" for subsequent DSB repair mechanisms. Together, these studies exemplify the possibility that pioneer processes are crucial for biological phenomena beyond transcriptional regulation.

\section{Acknowledgments}

We thank Makiko Iwafuchi and Paul R. Andreassen for critical reading of the manuscript.

\section{References}

Baker CL, Walker M, Kajita S, Petkov PM, Paigen K. 2014. PRDM9 binding organizes hotspot nucleosomes and limits 
Holliday junction migration. Genome Res 24: 724-732. doi:10 $.1101 /$ gr.170167.113

Brick K, Smagulova F, Khil P, Camerini-Otero RD, Petukhova GV. 2012. Genetic recombination is directed away from functional genomic elements in mice. Nature 485: 642-645. doi:10 $.1038 /$ nature 11089

De La Fuente R, Baumann C, Fan T, Schmidtmann A, Dobrinski I, Muegge K. 2006. Lsh is required for meiotic chromosome synapsis and retrotransposon silencing in female germ cells. Nat Cell Biol 8: 1448-1454. doi:10.1038/ncb1513

Grey C, Baudat F, de Massy B. 2018. PRDM9, a driver of the genetic map. PLoS Genet 14: e1007479. doi:10.1371/journal.pgen .1007479

Hunter N. 2015. Meiotic recombination: the essence of heredity. Cold Spring Harb Perspect Biol 7: a016618. doi:10.1101/ cshperspect.a016618

Iwafuchi-Doi M, Zaret KS. 2014. Pioneer transcription factors in cell reprogramming. Genes Dev 28: 2679-2692. doi:10.1101/ gad.253443.114

Jenness C, Giunta S, Müller MM, Kimura H, Muir TW, Funabiki H. 2018. HELLS and CDCA7 comprise a bipartite nucleosome remodeling complex defective in ICF syndrome. Proc Natl Acad Sci 115: E876-E885. doi:10.1073/pnas.1717509115
Lange J, Yamada S, Tischfield SE, Pan J, Kim S, Zhu X, Socci ND, Jasin M, Keeney S. 2016. The landscape of mouse meiotic double-strand break formation, processing, and repair. Cell 167: 695-708.e16. doi:10.1016/j.cell.2016.09.035

Maezawa S, Yukawa M, Alavattam KG, Barski A, Namekawa SH. 2018. Dynamic reorganization of open chromatin underlies diverse transcriptomes during spermatogenesis. Nucleic Acids Res 46: 593-608. doi:10.1093/nar/gkx1052

Paigen K, Petkov PM. 2018. PRDM9 and its role in genetic recombination. Trends Genet 34: 291-300. doi:10.1016/j.tig.2017.12 .017

Spruce C, Diamini S, Ananda G, Bronkema N, Tian H, Paigen K, Carter GW, Baker CL. 2020. HELLS and PRDM9 form a pioneer complex to open chromatin at meiotic recombination hot spots. Genes Dev (this issue). doi:10.1101/gad.333542.119

Unoki M, Funabiki H, Velasco G, Francastel C, Sasaki H. 2019. CDCA7 and HELLS mutations undermine nonhomologous end joining in centromeric instability syndrome. J Clin Invest 129: 78-92. doi:10.1172/JCI99751

Zeng W, Baumann C, Schmidtmann A, Honaramooz A, Tang L, Bondareva A, Dores C, Fan T, Xi S, Geiman T, et al. 2011. Lymphoid-specific helicase (HELLS) is essential for meiotic progression in mouse spermatocytes. Biol Reprod 84: 12351241. doi:10.1095/biolreprod.110.085720 


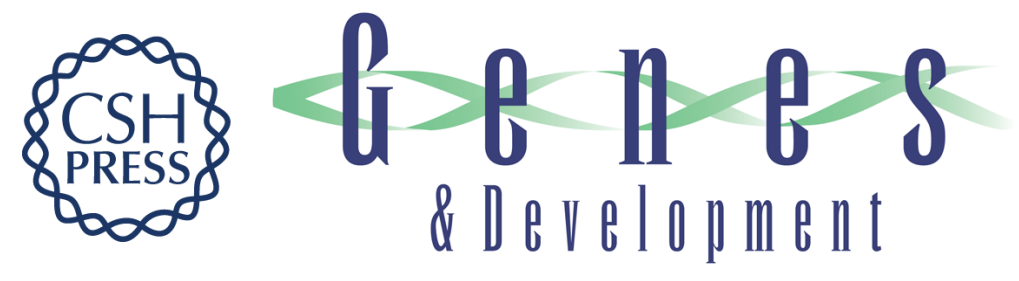

\section{Pioneering meiotic recombination}

Kris G. Alavattam, Hironori Abe and Satoshi H. Namekawa

Genes Dev. 2020, 34:

Access the most recent version at doi:10.1101/gad.336438.120

\section{Related Content HELLS and PRDM9 form a pioneer complex to open chromatin at meiotic recombination hot spots \\ Catrina Spruce, Sibongakonke Dlamini, Guruprasad Ananda, et al. \\ Genes Dev. March , 2020 34: 398-412}

References This article cites 13 articles, 5 of which can be accessed free at:

http://genesdev.cshlp.org/content/34/5-6/395.full.html\#ref-list-1

Articles cited in:

http://genesdev.cshlp.org/content/34/5-6/395.full.html\#related-urls

Creative This article is distributed exclusively by Cold Spring Harbor Laboratory Press for the first Commons

License

six months after the full-issue publication date (see

http://genesdev.cshlp.org/site/misc/terms.xhtml). After six months, it is available under a Creative Commons License (Attribution-NonCommercial 4.0 International), as described at http://creativecommons.org/licenses/by-nc/4.0/.

Email Alerting Receive free email alerts when new articles cite this article - sign up in the box at the top Service right corner of the article or click here.

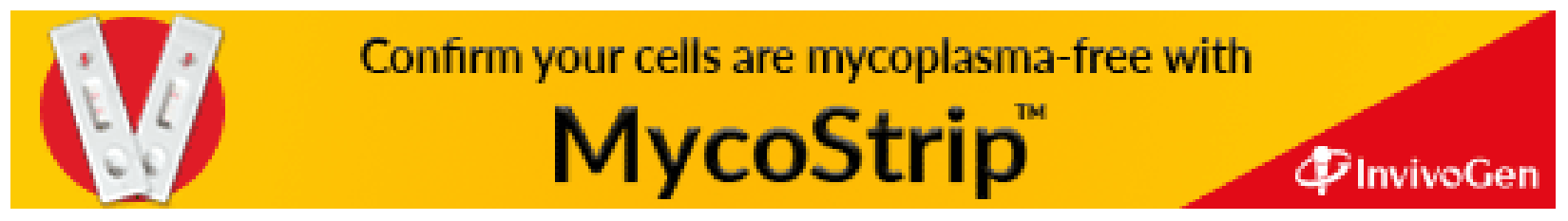

